\title{
Pelatihan Kewirusahaan Berbasis Internet : Tips dan Trik Sukses Berbisnis Online Bagi Remaja Milenial di Desa Kaduara Barat Pamekasan
}

\author{
Aflahah \\ Institut Agama Islam Negeri Madura \\ aflahah84@gmail.com \\ Mohammad Imam Sufiyanto \\ Institut Agama Islam Negeri Madura
}

\begin{abstract}
The way to maximize the potential of youth entrepreneurial spirit is through the internet-based entrepreneurship training program "Tips and Tricks for Online Business Success for Millennial Youth in the West Kaduara Village". This program is a community service activity carried out in the form of training, as well as creating sustainable and independent activities to increase entrepreneurial interest for millennial youth in the West Kaduara Village. This program will take place on Sunday, August 3, 2019, which consists of five activities, namely Study Online Shop, Achievement Motivation Training and Succsess Story, understanding of online shop platforms and social media knowledge. The first stage is the online shop study, this activity aims to provide knowledge and capture program targets, after the targets are obtained, the program continues with the provision of training and skills on online-based entrepreneurship which includes platform knowledge and success stories, understanding of the online shop, and knowledge of social media in business management. After the target has skills in developing the business, then the provision of understanding of social media is carried out as a step towards the realization of the target to practice the entrepreneurial spirit that they have learned. The program's success criteria result from the enthusiasm of millennial adolescents in managing the business that has been given to the target, namely increasing the level of target knowledge about the meaning of entrepreneurship, increasing target commitment in implementing entrepreneurship programs, and increasing entrepreneurial desire from the target.
\end{abstract}

Keywords: The Soul of Entrepreneurship; Social Media; Online Shop.

\begin{abstract}
Abstrak
Salah satu cara memaksimalkan potensi jiwa kewirausahaan remaja adalah melalui program Pelatihan kewirausahaan berbasis internet "Tips dan Trik Sukses Berbisnis Online Bagi Remaja Milenial di Desa Kaduara Barat". Program ini merupakan kegiatan pengabdian masyarakat yang dilaksanakan dalam bentuk pelatihan, serta membuat kegiatan berkelanjutan yang mandiri dan produktif untuk meningkatkan minat kewirausahaan bagi remaja milenial di Desa Kaduara Barat. Program ini berlangsung pada Ahad tanggal 3 Agustus 2019 yang terdiri dari lima kegiatan, yaitu Study online Shop, Achievment Motivation Training dan Succsess Story, pemahaman platform online shop dan pengetahuan media sosial. Tahapan pertama adalah study online shop, kegiatan ini bertujuan untuk memberikan pengetahuan serta menjaring sasaran program, setelah sasaran diperoleh, maka program dilanjutkan dengan pemberian pelatihan dan keterampilan mengenai kewirausahaan berbasis online yang meliputi pengetahuan platform dan Succsess Story, pemahaman online shop, dan pengetahuan media sosial dalam pengelolaan usaha. Setelah sasaran memiliki keterampilan dalam mengembangkan usaha, maka pemberian pemahaman media sosial dilaksanakan sebagai langkah realisasi sasaran untuk mempraktekan jiwa kewirausahaan yang mereka telah pelajari. Kriteria keberhasilan program dihasilkan dari antusiasme remaja milenial dalam mngelola usaha yang telah diberikan kepada sasaran yaitu meningkatnya tingkat pengetahuan sasaran mengenai arti kewirausahaan, meningkatnya komitmen sasaran dalam melaksanakan program kewirausahaan, dan meningkatnya keinginan berwirausaha dari sasaran.
\end{abstract}




\section{Pendahuluan}

Seiring perkembangan zaman, dibutuhkan jiwa-jiwa kewirausahaan yang tumbuh dari generasi muda untuk menopang perekonomian nasional melalui aktifitas wirausaha. Hal ini sangat penting untuk menciptakan lapangan kerja mandiri, sebagai salah satu strategi untuk mengatasi masalah pengangguran yang meningkat di Indonesia.

Jiwa kewirausahaan sebenarnya hampir dimiliki oleh setiap generasi muda, namun kurangnya pengetahuan dan pelatihan kewirausahan menyebabkan generasi muda saat ini kurang memaksimalkan potensi jiwa kewirausahaan. Disamping banyak faktor lain yang menyebabkan hal tersebut, seperti kurangnya modal ataupun jaringan yang sangat sedikit sehingga sangat sulit untuk mengembangkan usaha dan jiwa kewirausahaan.

Pengembangan kemampuan berwirausaha merupakan alternatif para remaja untuk lepas dari pengangguran terutama bagi mereka yang tidak bisa melanjutkan sekolah kejenjang yang lebih tinggi. Pengembangan jiwa kewirausahaan melalui pemberian dan pelatihan dapat dijadikan salah satu alternatif kegiatan remaja yang bersifat positif. Para remaja dapat memanfaatkan waktunya daripada menghabiskan waktu dengan hal-hal yang tidak berguna seperti "nongkrong", dan lain sebagainya.

Sasaran yang ditargetkan adalah para remaja di desa kaduara Barat.

\section{Kajian Pustaka}

\section{A. Gambaran Umum Masyarakat Sasaran dalam Minat kewirausahaan}

Gambaran secara umum sasaran adalah remaja Desa Kaduara Barat yang berasal dari kalangan keluarga ekonomi bawah, rata-rata mereka tidak melanjutkan ke jenjang pendidikan lebih tinggi dan pada usia produktif (15-55 tahun) dengan tujuan memperkenalkan dan mengembangkan sejak dini jiwa kewirausahaan mereka.

Pengembangan dalam minat remaja dikembangkan dengan maksud untuk mengatasi masalah ketenagakerjaan melalui penyiapan tenaga kerja yang terampil untuk dunia usaha dan dunia industri. Harapan ini nampaknya belum seperti yang diharapkan. Faktanya saat ini pemuda cenderung menjadi pencari kerja dan sangat sedikit yang menjadi pencipta lapangan kerja.

\section{B. Berbisnis Online}

Terlepas dari semakin mudahnya pelaku bisnis dan konsumen melakukan hubungan jual beli sebagai akibat dari perkembangan teknologi dan informasi, namun demikian ada risiko yang harus dihadapi khususnya dalam hal kepercayaan. Kasus penipuan beberapa kali di dunia bisnis online sehingga faktor kepercayaan menjadi hal yang sangat diperhatikan oleh konsumen online. Dalam beberapa studinya menemukan bahwa bahwa faktor risiko yang dirasakan dan kepercayaan memiliki pengaruh yang kuat pada minat beli yang berujung pada keputusan pembelian yang dibuat oleh konsumen. ${ }^{1}$

Agar dapat dijalankan dengan baik, sebuah bisnis, khususnya pada aspek pemasarannya, perlu bersungguh-sungguh dalam memahami faktor-faktor yang dapat menimbulkan minat beli konsumen secara online, khususnya yang berhubungan dengan kepercayaan. Berdasarkan uraian maka perlu dilakukan penelitian peran faktor risiko yang dirasakan dan pada minat beli online konsumen. Dengan demikian penelitian ini dapat dijadikan masukan bagi pelaku bisnis online agar lebih dapat memahami konsumennya serta dapat menjadi rujukan bagi penelitian yang khususnya membahas mengenai pemasaran bisnis online mengingat sedikitnya penelitian yang membahas masalah ini di pasar Indonesia. ${ }^{2}$

\footnotetext{
${ }^{1}$ Rosihan Anwar and Wijaya Adidarma, "Pengaruh Kepercayaan Dan Risiko Pada Minat Beli Belanja Online,” Jurnal Manajemen Dan Bisnis Sriwijaya 14, no. 2 (2016): 155-168.

2 Erlinda Nordiana, "Peran Jejaring Sosial Sebagai Media Peningkat Minat Berwirausaha
} 
Keberadaan internet telah mengubah berbagai aktivitas masyarakat, tidak terkecuali dalam transaksi jual beli. Tingginya jumlah masyarakat Indonesia yang mulai terbiasa dengan jual beli online berdampak pada munculnya pelaku bisnis online. Pelaku bisnis perlu memahami perubahan perilaku konsumen yang terjadi agar proses bisnis yang dijalankan dapat diterima dengan baik oleh konsumen. Dalam menyusun sebuah proses bisnis online, pelaku perlu mengerti faktor-faktor yang berpengaruh kuat terhadap minat beli konsumen secara online. Dengan memahami faktor-faktor yang mempengaruhi minat pembelian online secara signifikan, maka pelaku dapat memaksimalkan aktivitas bisnisnya untuk memperoleh hasil yang maksimal. Oleh karena itu, studi ini bertujuan untuk mengetahui pengaruh kepercayaan pada risiko yang dirasakan konsumen dalam transaksi belanja online, juga untuk mengetahui pengaruh risiko dan kepercayaan pada minat beli belanja online.

Minat berwirausaha akan menjadikan seseorang lebih giat mencari dan memanfaatkan peluang usaha dengan mengoptimalkan potensi yang dimiliki. Minat berwirausaha merupakan keinginan, ketertarikan, serta kesediaan individu untuk bekerja keras dalam memenuhi kebutuhan hidupnya tanpa takut dengan resiko yang akan terjadi. Minat berperan sangat penting dalam kehidupan peserta didik dan mempunyai dampak yang besar terhadap sikap dan perilaku. Siswa yang memiliki minat terhadap sesuatu cenderung mempunyai ketertarikan untuk mengetahui dan mempelajari hal-hal yang berkaitan dengan minat tanpa adanya paksaan. Seseorang dikatakan memiliki minat berwirausaha yang tinggi dapat dilihat dari berbagai aspek kepribadian seperti watak, sikap dan perilaku seseorang. ${ }^{3}$

\section{Pemberdayaan Masyarakat}

Keuntungan penerapan pembangunan berorientasi/berpusat pada rakyat adalah: kelancaran pelaksanaan berbagai kegiatan, koordinasi dapat dibangun secara harmonis dan lancar, terbangun rasa simpatik masyarakat terhadap karya pembangunan, menumbuhkan tanggung jawab dalam memelihara sarana prasarana yang telah dibangun bersama serta kendala yang timbul atau akan timbul dapat diatasi secara lebih mudah dan dini.

Penerapan pemberdayaan masyarakat paling banyak digunakan di sektor ekonomi, khususnya yang berkaitan dengan penanggulangan kemiskinan. Empat jalur strategis yang digunakan dalam pemberdayaan masyarakat, yaitu perluasan kesempatan, penguatan kelembagaan, peningkatan kapasitas, dan perlindungan sosial. Perluasan kesempatan ditujukan untuk menciptakan kondisi dan lingkungan ekonomi, politik, dan sosial yang memungkinkan masyarakat miskin memperoleh kesempatan seluas-luasnya dalam pemenuhan kebutuhan dasar dan peningkatan taraf hdiup secara berkelanjutan. Penguatan kelembagaan untuk menjamin semua masyarakat miskin untuk berpartisipasi dalam pengambilan keputusan publik yang menjamin perlindungan dan pemenuhan hak-hak dasar secara berkelanjutan.

Pemberdayaan masyarakat memiliki tiga sisi yaitu penyadaran, pembangunan kapasitas, dan pendayaan. Pada sisi pertama, penyadaran, target masyarakat diberikan pemahaman-pemahan tentang hak-hak yang seharusya dimiliki. Kegiatan yang dapat dilakukan pada tahapan ini adalah memberikan pengetahuan yang bersifat kognisi, kepercayaan, dan penyembuhan. Sisi kedua adalah peningkatan kapasitas atau memberikan kemampuan. Peningkatan kapasitas terdiri

Mahasiswa Untuk Berbisnis Online (Studi Pada Mahasiswa Jurusan IImu Ekonomi Universitas Brawijaya)," Jurnal Ilmiah Mahasiswa FEB 2, no. 2 (2013).

3 Lutfiadi and Rahmanto, "Analisis Peran Pendidikan Kewirausahaan, Kepribadian, Dan Lingkungan Terhadap Minat Siswa SMK Untuk Berwirausaha Di Kota Bekasi." 
dari tiga jenis yaitu manusia, organisasi, dan sistem nilai.Sisi terakhir adalah pendayaan. Memberikan daya, kekuasaan, otoritas, atau peluang. ${ }^{4}$

Pemberdayaan (empowerement) merupakan salah satu fungsi pemerintahan yang mengedapankan kepada optimalisasi potensi-potensi yang diperintah (masyarakat) baik potensi sumber daya manusia maupun optimalisasi sumber daya alam yang dikelola oleh manusia yang memiliki keretampilan khusus dan khas.

\section{Pelaksanaan Kegiatan}

\section{A. Bidang Kegiatan yang Dipilih: Program Sosialisasi Pelatihan Kewirausahaan}

1. Pengenalan Platform

Tahapan ini dilaksanakan pada tanggal 3 Agustus 2019 berlokasi di Desa Kaduara Barat. Tujuan pengenalan platform yaitu mendapatkan sasaran dari remaja milenial di Desa Kaduara Barat untuk mengikuti program pelatihan kewirausahaan ini. Setelah peserta didapatkan, selanjutnya diadakan sosialisasi dalam diskusi.

Pengenalan platform dilakukan agar peserta dapat memahami berbagai macam platform didalam beranda media sosial maupun playstore yang tersedia di Hp maupun Laptop yang berbasis internet sehingga dapat mengenal jenis-jenis distributor dalam mengenal pemasaran berbasis internet.

2. Pemberian Materi

Dalam pelaksanaan pemberian materi dibagi menjadi 3 bagian yaitu:

a. Success Story dan Achievement Motivation Training

Success Story dan Achievement Motivation Training dilaksanakan Materi Success Story yang dibawakan oleh bapak Moh. Imam Sufiyanto sebagai dosen pengampu mata kuliah wirausaha dan pemberi motivator dalam menggerakkan mahasiswa untuk berwirausaha. Beliau menceritakan tentang perjalanan sukses usaha-usaha menengah kebawah yang dimulai dari program kreatifitas mahasiswa bidang kewirausahaan yang terus berlanjut hingga saat ini usahanya semakin berkembang pesat. Pada kegiatan ini menjelaskan tentang kiat-kiat sukses Kerang ljo dalam menjalankan usahanya.

Sedangkan untuk pemberian Achievement Motivation Training (AMT) adalah Inti acara ini menumbuhkan motivasi bagi para peserta untuk berani memulai usaha sendiri dan menimbulkan jiwa kewirausahaan pada diri mereka. Dalam tahap ini diadakan tanya jawab dengan peserta secara langsung. Program secara keseluruhan berjalan lancar dan sukses. Peralatan yang digunakan antara lain ruang pertemuan, kursi, meja, white board, laptop, LCD, speaker dan roll kabel.

a. Pelatihan Camilan Crispy dan handycraft

Pada pelatihan Camilan Crispy dari berbagai macam produk pemberdayaan masyarakat yang dihasilkan berupa cumi crispy, teri crispy, dan lele crsipy dan sesi kedua pelatihan mute-mute dan gantungan tas, bros, dan brenda. Pelatih dari tim pengusul memberi penjelasan tentang camilan crispy dan kerajinan dari mute-mute. Peserta segera dibagi menjadi kelompok-kelompok sesuai dengan supervisor kelompoknya. Selanjutnya peserta dibagi menjadi 2 kelompok kecil, masing-masing kelompok terdiri dari 10 orang. Kelompok 1 mempelajari pemembuatan Camilan Crsipy dan kelompok 2 mempelajari pembuatan kerajinan mute-mute dan gantungan tas, bros dan Brenda.

b. Manajemen Pengelolaan Usaha

Pelaksanaan kegiatan manajemen pengelolaan usaha ini dimulai setelah para peserta masuk, MC segera memperkenalkan pembicara kepada peserta.

\footnotetext{
${ }^{4}$ Randy R. Wrihatnolo dan Riant N. Dwidjowijoto, Manajemen Pemberdayaan Sebuah Pengantar dan Panduan untuk Pemberdayaan Masyarakat (Jakarta. PT. ElexMedia
} Komputindo, 2007), hlm. 3-7. 
Pembicara dalam hal ini adalah ibu Aflahah sebagai ketua Prodi PGMI. Setelah perkenalan maka pembicara segera memulai presentasi, dimana pembicara mengajarkan kepada peserta pentingnya manajemen dalam suatu perusahaan. Pembicara menyampaikan materi tentang bagaimana cara peserta mengelola perusahaan, mulai dari manajemen keuangan, sumber daya manusia, dan cara pembuatan proposal usaha yang baik. Acara berlangsung selama satu setengah jam dan diakhiri dengan diskusi dan tanya jawab.

3. Pengetahuan Media Sosial

Memberi pengetahuan dalam menggunakan media sosial yang bertujuan untuk mengembangkan kewirausahaan berbasis internet sehingga dapat membentuk komunitas wirausahaan di sektor makanan dan Handycraft sebagai salah satu produk wirausaha yang akan dipromosikan kedalam jejaring sosial dan media sosial pada tahap ini diberikan pemahaman kemada kaum remaja milenial agar bisa menyusun strategi promosi dan kelebihan-kelebihan sesuai dengan produk.

\section{Penutupan}

Dilaksanakan pada tanggal 3 Agustus 2019 di desa Kaduara Barat. Kegiatan ini merupakan penutupan dari seluruh rangkaian acara program PKM. Kegiatan ini meliputi pengumpulan jenis-jenis camilan dan produk-produk Handycraft dari masing-masing kelompok, pemberian kuisioner akhir kepada para sasaran, Kuisioner akhir tersebut dibandingkan dengan kuisioner awal yang sebelumnya telah diisi oleh sasaran. Dari hasil perbandingan tersebut tergambar bahwa telah terjadi perubahan positif dari sikap sasaran terhadap kewirausahaan. Untuk menindaklanjuti perubahan sikap tersebut, maka tim pelaksana melakukan monitoring secara kontinu terhadap kegitan kewirausahaan sasaran.

\section{B. Maksud, Tujuan, dan Sasaran yang ingin dicapai}

Program pelatihan kewirausahaan berbasis internet ini merupakan aplikasi dari ilmu pengetahuan yang kemudian dapat diimplikasikan dalam kehidupan bermasyarakat dengan prinsip saling menolong guna meningkatkan kesejahteraan hidup. Dengan harapan setelah adanya sosialisasi akan terbentuk sebuah kumunitas usaha di daerah Kaduara Barat.

Program ini bertujuan untuk memberikan pemahaman tentang pentingnya berwirausaha terkait dengan pengertian, tujuan dan manfaat wirausaha dalam meningkatkan kesejahteraan dan mendorong perekonomian menjadi lebih baik. Adapun sasaran dalam kegiatan ini adalah masyarakat sekitar daerah Kaduara Barat.

\section{Waktu Pelaksanaan \\ Hari : Sabtu \\ Tanggal : 03 Agustus 2019 \\ Pukul : 08.00-11.30 WIB}

\section{Hasil yang Dicapai dan Tindak Lanjut}

Ketercapaian target luaran dalam program ini meliputi perubahan pengetahuan tentang kewirausahaan, komitmen mengikuti pelatihan, dan minat berwirausaha dari peserta. Ketercapaian target luaran ini diukur dengan menggunakan kuesioner. Selain itu program ini juga menghasilkan produk berupa gantungan tas, bros, asessoris pensil, boneka, foto, tempat pensil, dan kerajinan dari kain flanel berupa tempat pensil dan kalung. Di bawah ini terdapat grafik-grafik yang menggambarkan perubahan sikap (pengetahuan kewirausahaan, komitmen mengikuti pelatihan, dan minat berwirausaha) dari peserta.

Pengetahuan kewirausahaan sasaran, pada waktu sebelum pelatihan diberikan masih terdapat $4,76 \%$ sasaran yang belum mengetahui tentang kewirausahaan. Pada waktu sesudah pelatihan diberikan semua sasaran (100\%) telah 
mengetahui apa kewirausahaaan. Berarti berdasarkan data ini pelatihan yang diberikan telah mampu memberikan tambahan pengetahuan tentang kewirausahaan.

Komitmen untuk mengikuti program pelatihan kewirausahaan dibagi menjadi empat kelompok, yaitu rendah ( $<25 \%)$, sedang $(25-50 \%)$, baik $(51-75 \%)$, dan sangat baik $(>75 \%)$. Berdasarkan pengolahan data dari kuesioner pada saat sebelum ataupun sesudah pelatihan diberikan komitmen rendah dari sasaran tidak ada dan komitmen sangat baik meningkat dari 47,62\% menjadi 57,15\%. Dalam hal ini berarti terjadi peningkatan komitmen sangat baik setelah diberikan pelatihan kewirausahaaan dengan indikator peningkatan minat $>75 \%$ (sangat baik) dari $47,62 \%$ menjadi $57,15 \%$.

Minat berwirausaha sasaran dibagi menjadi empat kelompok, yaitu rendah $(<25 \%)$, sedang $(25-50 \%)$, baik $(51-75 \%)$, dan sangat baik $(>75 \%)$. Berdasarkan pengolahan data kuesioner dihasilkan minat rendah tidak ada sama sekali dan minat baik meningkat dari 38,09\% menjadi 42,85\%. Dalam hal ini berarti terjadi peningkatan minat yang baik untuk berwirausaha dari sasaran dengan indikator minat berwirausaha 51\%-75\% (baik) dari 38,09\%- 42,85\%.

Ketercapaian lainnya berupa produk-produk yang terlihat pada gambar dokumentasi produk yang dihasilkan dan keberhasilan penjualannya yang terlihat pada lampiran laporan laba-rugi kelompok. Rata-rata setiap kelompok dari modal yang diberikan dapat memproduksi gantungan kunci 50 buah @Rp 2.000,-, kalung 10 buah @Rp 10.000,- dan gelang 20 buah @ Rp 7.500,-, tempat pensil kain flanel 5 buah @Rp 5.000,- dan kerajinan bros 2 buah @ Rp 20.000,-.

\section{E. Faktor Pendukung dan Faktor Penghambat Faktor Pendukung}

Program pelatihan wirausaha berbasis internet berjalan dengan lancar. Hal ini dikarenakan semua peserta semangat dan antusias dalam mendengarkan pemaparan materi serta tanya jawab yang berlangsung.

\section{Faktor Penghambat}

Dengan diadakannya sosialisasi tersebut, para pemuda mengharapkan partisipasi dan dukungan dari masyarakat, tetapi sampai saat ini belum ada respon dari tokoh dan masyarakat. Hal ini dikarenakan kebanyakan masyarakat sibuk dengan aktifitas pribadi. Namun remaja tidak berputus asa sampai disini.

\section{Kesimpulan Dan Saran}

\section{A. Kesimpulan}

Program "Sukses Berbisnis Online Bagi Remaja Milenial di Desa Kaduara Barat" telah dilaksanakan sesuai dengan rencana pada proposal awal. Tujuan utama dari program kreativitas mahasiswa bidang pengabdian masyarakat adalah perubahan dari sikap para sasaran. Perubahan sikap yang diharapkan dari program ini adalah perubahan motivasi dan minat untuk berwirausaha dari sasaran yaitu remaja di Desa Kaduara Barat. Berdasarkan pengukuran kuesioner yang diberikan melalui pre-test dan post-test terlihat adanya perubahan sikap yang positif atau lebih baik. Hal ini dapat terlihat pada tahap hasil dan pembahasan.

\section{B. Saran}

Saran-saran yang dapat diberikan pada pelaksanaan program ini adalah:

1) Program ini dapat dilaksanakan dan diterapkan untuk sasaran lain, misalnya anak-anak muda pengangguran ataupun pada karang taruna.

2) Pemberian pelatihan yang lebih beragam lagi disesuaikan dengan kebutuhan para sasaran. 


\section{Daftar Pustaka}

Alfianto, E. Agus. Kewirausahaan Sebuah Kajian Pengabdian Kepada Masyarakat. Pasuruan: Universitas Yudartha. 2012.

Anggraeni dan Hamalik. Pengaruh Pengetahuan Kewirausahaan dan Lingkungan. Universitas Semarang: Unmes. 2015.

Nordiana, Erlinda. "Peran Jejaring Sosial Sebagai Media Peningkat Minat Berwirausaha Mahasiswa Untuk Berbisnis Online (Studi Pada Mahasiswa Jurusan IImu Ekonomi Universitas Brawijaya)," Jurnal IImiah Mahasiswa FEB 2, no. 2 (2013).

Lutfiadi dan Rahmanto. Analisis Peran Pendidikan Kewirausahaan, Kepribadian dan Lingkungan. Yogyakarta. 2011.

Randy, R. Wrihatnolo dan Riant N. Dwidjowijoto. Manajemen Pemberdayaan Sebuah Pengantar dan Panduan untuk Pemberdayaan Masyarakat. Jakarta. PT. Elex Media Komputindo, 2007.

Rosihan, Anwar dan Wijaya Adidarma. "Pengaruh Kepercayaan Dan Risiko Pada Minat Beli Belanja Online," Jurnal Manajemen Dan Bisnis Sriwijaya 14, no. 2 (2016).

Sumitro, Maskun. Pembangunan Masyarakat Desa: Asas, Kebijaksanaan dan Manajemen. Yogyakarta: MW Mandala, 1994 